\title{
Effect of Foliar Application of Growth Regulators and Micronutrients on Fruit Yield Attributes of Acid Lime (Citrus aurantifolia Swingle)
}

\author{
N. Vasure*, A.K. Barholia, R. Bajpai, R. Jatav and R. Pippal
}

Department of Horticulture, College of Agriculture, R.V.S.K.V.V., Gwalior (M.P.), India

*Corresponding author

\section{A B S T R A C T}

\section{Keywords \\ Acid lime, Plant growth regulators, \\ Micronutrients, Yield \\ attributes, Variety \\ Article Info \\ Accepted: \\ 04 August 2018 \\ Available Online: \\ 10 September 2018}

The present study was conducted at the Agrotechnology Park, Krishi Vigyan Kendra, College of Agriculture, Gwalior, Rajmata Vijyaraje Scindia Krishi Vishwa Vidyalaya, Gwalior (M.P.) during the year 2015-16 and 2016-17. The experiment was laid out in Randomized Block Design (RBD). Seventy four uniform healthy acid lime trees, planted at $6 \times 6$ m distance were selected under the present study. The experiment consisted of 24 treatment combinations out of six the combination of growth regulators and micronutrients with control and four acid lime varieties. In this manuscript various yield parameters such as number of fruits per tree, fruits yield per tree and fruits yield per hectare have discussed here in respect of foliar application of growth regulators and micronutrients on acid lime varieties.

\section{Introduction}

Acid lime (Citrus aurantifolia Swingle) is one of the most important fruit crop of India, is generally known as 'Nimbu'. It is belongs to the family Rutaceae probably originated in India and then spread to the Middle East and other tropical and subtropical countries (Salunkhe and Desai, 1984). It is mainly cultivated for its multi - fold nutritional and medicinal values, which made acid lime more important among the fruits. Its attractive appearance, penetrating aroma of peel and excellent taste gives a remarkable position to acid lime which is grown widely throughout the world (Babu, 2001). The genus Citrus is economically very important and is known for its juice and pulp throughout the world. In
India, acid lime is grown in a variety of agroclimates comprising from the northern plains and central highlands having hot semi-arid eco-region with black and red soils. There is difficulty in fruit set because of incomplete pollination, hence plant growth regulators and micronutrients may be effectively used to increase fruit set as well increase fruit yield.

Nutritional deficiencies are closely associated with the poor plant growth and fruit set, heavy fruit drop, inferior quality of produce and also make the tree vulnerable to diseases, pests and other disorders. Nutrients like nitrogen, phosphorus and potash play a vital role in promoting the plant vigour and productivity, whereas micronutrients like zinc, boron, copper and Magnesium perform a specific role 
in the growth and development of plant, quality produce and uptake of major nutrients. On the other hand, plant growth regulators refer to organic compounds other than nutrients which in small quantities promote, inhibit or otherwise modify any plant physiological process. Plant hormones refer to bio-regulators produced by the plant which usually move within the plant from the site of production to the site of action and regulate plant physiological process at very low concentration. Plant growth substances have key role in different physiological processes related to growth and development of crops. It is obvious that changes in the level of endogenous hormones due to biotic and abiotic stress alter the crop growth and any sort of manipulation including exogenous application of growth substances would help for yield improvement or at least sustenance of the crop.

\section{Materials and Methods}

Eight year old bearing Acid lime trees of uniform vigour and size were selected for the present study. The experiment consisted of 24 treatment combinations out of six the combination of growth regulators and micronutrients and four acid lime varieties.

\section{Treatment details}

Factor A - Growth regulators and micronutrients $(5+1$ control $)$

$\mathrm{A}_{1}-\mathrm{GA} 350 \mathrm{ppm}+\mathrm{KNO}_{3}(0.2 \%)$

$\mathrm{A}_{2}-\mathrm{GA} 350 \mathrm{ppm}+\mathrm{KNO}_{3}(0.2 \%)+\mathrm{ZnSO} 4$ $(0.3 \%)$

$\mathrm{A}_{3}-\mathrm{GA}_{3} 50 \mathrm{ppm}+\mathrm{KNO}_{3}(0.2 \%)+\mathrm{ZnSO} 4$ $(0.3 \%)+$ Boron $(0.1 \%)$

$\mathrm{A}_{4}-\mathrm{GA} 3$ 50ppm+ Cycocel 1000ppm $+\mathrm{KNO}_{3}$ $(0.2 \%)+\mathrm{ZnSO} 4(0.3 \%)+$ Boron $(0.1 \%)$
$\mathrm{A}_{5}-\mathrm{GA} 350 \mathrm{ppm}+$ Cycocel 2000ppm $+\mathrm{KNO}_{3}$ $(0.2 \%)+\mathrm{ZnSO}_{4}(0.3 \%)+$ Boron $(0.1 \%)$

$\mathrm{A}_{6^{-}}$Control

Factor B - Varieties (4)

$\mathrm{B}_{1}-$ Kagzi lime

$\mathrm{B}_{2}$-Vikram

$\mathrm{B}_{3}$--Pramalini

$\mathrm{B}_{4}$--Sai Sarbati

To test the significance of variation in the data obtained from various characters. The technique of analysis of variance was adopted as suggested by Fisher (1950) for randomized block design.

\section{Results and Discussion}

\section{Number of fruits per tree}

The data concerning the number of fruits per tree are shown in (Table 1). Maximum number of fruits per tree counted under $\mathrm{A}_{5}\left(\mathrm{GA}_{3} 50\right.$ ppm + Cycocel 2000 ppm+ KNO3@0.2\% $+\mathrm{ZnSO} 4$ @ 0.3\% + Boron @ 0.1\%) i.e. 878.49, 918.60 and 898.54 followed by $\mathrm{A}_{4}$ (GA3 50 ppm + Cycocel 1000 ppm+ KNO3@ $0.2 \%+\mathrm{ZnSO}_{4} @ 0.3 \%+$ Boron @ 0.1\%) i.e. 811.64, 849.88 and 830.76, $\mathrm{A}_{3}(\mathrm{GA} 350 \mathrm{ppm}+$ KNO3@0.2\%+2nSO ${ }_{4} @ 0.3 \%+$ Boron@ $0.1 \%)$ i.e. 772.35, 809.00 and 790.68 while the minimum number of fruits per tree recorded under $\mathrm{A}_{6}$ (Control) i.e. 654.21, 686.23 and 670.22 during first year, second year and pooled data.

Among the different varieties, $\mathrm{B}_{4}$ (Sai Sarbati) noted maximum number of fruits per tree i.e. $773.79,805.67$ and 789.73. It was followed by $\mathrm{B}_{3}$ (Pramalini) i.e. 767.90, 809.85 and 788.88 and $\mathrm{B}_{2}$ (Vikram) i.e. 758.74, 794.49 and 776.61 while the minimum number of fruits per tree recorded with $\mathrm{B}_{1}$ (Kagzi lime) i.e. 749.84, 784.34 and 767.09 during first year, 
second year and pooled data. All the varieties were found insignificant to each other.

\section{Yield per tree}

An assessment of data presented in Table 2 revealed that the maximum yield per tree observed under $\mathrm{A}_{5}\left(\mathrm{GA}_{3} 50 \mathrm{ppm}+\right.$ Cycocel 2000 ppm+KNO3@0.2\%+ZnSO $@ 0.3 \%+$ Boron@0.1\%) i.e. $44.55 \mathrm{~kg}, 49.47 \mathrm{~kg}$ and $47.01 \mathrm{~kg}$ followed by $\mathrm{A}_{4}(\mathrm{GA} 350 \mathrm{ppm}+$ Cycocel 1000 ppm+ KNO3@0.2\%+ZnSO4 @ 0.3\%+Boron@0.1\%) i.e. $38.30 \mathrm{~kg}, 41.73$ $\mathrm{kg}$ and $40.02 \mathrm{~kg}, \mathrm{~A}_{3}(\mathrm{GA} 350 \mathrm{ppm}+\mathrm{KNO} 3 @$ 0.2\%+ZnSO $\mathrm{Zn}_{4} @ 0.3 \%+$ Boron@0.1\%)i.e.
$34.85 \mathrm{~kg}, 38.12 \mathrm{~kg}$ and $36.49 \mathrm{~kg}$ while the minimum yield per tree recorded under $\mathrm{A}_{6}$ (Control) i.e. $25.41 \mathrm{~kg}, 28.15 \mathrm{~kg}$ and $26.78 \mathrm{~kg}$ during first year, second year and pooled data.

The variety $\mathrm{B}_{4}$ (Sai Sarbati) recorded maximum yield per tree i.e. $35.30 \mathrm{~kg}, 39.16$ $\mathrm{kg}$ and $37.16 \mathrm{~kg}$. It was followed by $\mathrm{B}_{3}$ (Pramalini) i.e. $34.71 \mathrm{~kg}, 38.21 \mathrm{~kg}$ and 36.46 $\mathrm{kg}$ and $\mathrm{B}_{2}$ (Vikram) i.e. $33.90 \mathrm{~kg}, 37.10 \mathrm{~kg}$ and $35.50 \mathrm{~kg}$ while the minimum yield per tree recorded with $\mathrm{B}_{1}$ (Kagzi lime) i.e. 33.10 $\mathrm{kg}, 36.21 \mathrm{~kg}$ and $34.66 \mathrm{~kg}$ during first year, second year and pooled data. All the varieties were found insignificant to each other.

Table.1 Effect of foliar application of growth regulators and micronutrients on number of fruits per tree of different acid lime varieties as influenced by growth regulators and Micronutrient treatments

\begin{tabular}{|c|c|c|c|}
\hline \multirow{2}{*}{$\begin{array}{l}\text { (A) PGR and } \\
\text { micronutrients }\end{array}$} & \multicolumn{3}{|c|}{ Number of fruits per tree } \\
\hline & IY & IY & IY \\
\hline $\mathbf{A}_{1}$ & 708.95 & 743.29 & 726.12 \\
\hline $\mathbf{A}_{2}$ & 749.77 & 784.52 & 767.15 \\
\hline $\mathbf{A}_{\mathbf{3}}$ & 772.35 & 809.00 & 790.68 \\
\hline $\mathbf{A}_{4}$ & 811.64 & 849.88 & 830.76 \\
\hline $\mathbf{A}_{5}$ & 878.49 & 918.60 & 898.54 \\
\hline $\mathbf{A}_{6}$ & 654.21 & 686.23 & 670.22 \\
\hline $\mathrm{SE}(\mathrm{m})$ & 7.00 & 8.29 & 4.99 \\
\hline CD $(5 \%)$ & 19.96 & 23.63 & 14.21 \\
\hline \multicolumn{4}{|l|}{ (B) Varieties } \\
\hline $\mathbf{B}_{1}$ & 749.84 & 784.34 & 767.09 \\
\hline $\mathbf{B}_{2}$ & 758.74 & 794.49 & 776.61 \\
\hline $\mathbf{B}_{\mathbf{3}}$ & 767.90 & 809.85 & 788.88 \\
\hline $\mathbf{B}_{4}$ & 773.79 & 805.67 & 789.73 \\
\hline $\mathbf{S E}(\mathbf{m})$ & 5.72 & 6.77 & 4.07 \\
\hline CD (5\%) & 16.30 & 19.29 & 11.60 \\
\hline
\end{tabular}


Table.2 Effect of foliar application of growth regulators and micronutrients on yield per tree $(\mathrm{kg})$ of different acid lime varieties as influenced by growth regulators and micronutrient treatments

\begin{tabular}{|c|c|c|c|}
\hline \multirow{2}{*}{$\begin{array}{l}\text { (A) PGR and } \\
\text { micronutrients }\end{array}$} & \multicolumn{3}{|c|}{ Yield per tree (kg) } \\
\hline & IY & IY & IY \\
\hline $\mathbf{A}_{1}$ & 29.54 & 32.56 & 31.05 \\
\hline $\mathbf{A}_{2}$ & 32.86 & 35.98 & 34.42 \\
\hline$\overline{\mathbf{A}_{3}}$ & 34.85 & 38.12 & 36.49 \\
\hline $\mathbf{A}_{4}$ & 38.30 & 41.73 & 40.02 \\
\hline $\mathbf{A}_{5}$ & 44.55 & 49.47 & 47.01 \\
\hline $\mathbf{A}_{6}$ & 25.41 & 28.15 & 26.78 \\
\hline $\mathrm{SE}(\mathrm{m})$ & 0.33 & 0.68 & 0.37 \\
\hline CD (5\%) & 0.95 & 1.94 & 1.04 \\
\hline \multicolumn{4}{|l|}{ (B) Varieties } \\
\hline $\mathbf{B}_{1}$ & 33.10 & 36.21 & 34.66 \\
\hline $\mathbf{B}_{2}$ & 33.90 & 37.10 & 35.50 \\
\hline $\mathbf{B}_{3}$ & 34.71 & 38.21 & 36.46 \\
\hline $\mathbf{B}_{4}$ & 35.30 & 39.16 & 37.23 \\
\hline SE (m) & 0.27 & 0.56 & 0.30 \\
\hline CD (5\%) & 0.77 & 1.59 & 0.85 \\
\hline
\end{tabular}

Table.3 Effect of foliar application of growth regulators and micronutrients on yield per ha (q) of different acid lime varieties as influenced by growth regulators and micronutrient treatments

\begin{tabular}{|c|c|c|c|}
\hline \multirow{2}{*}{$\begin{array}{l}\text { (A) PGR and } \\
\text { micronutrients }\end{array}$} & \multicolumn{3}{|c|}{ Yield per ha (q) } \\
\hline & IY & IY & IY \\
\hline $\mathbf{A}_{1}$ & 81.82 & 90.18 & 86.00 \\
\hline$\overline{\mathbf{A}_{2}}$ & 91.01 & 99.68 & 95.35 \\
\hline $\mathbf{A}_{\mathbf{3}}$ & 96.54 & 105.60 & 101.07 \\
\hline$\overline{\mathbf{A}_{4}}$ & 106.09 & 115.59 & 110.84 \\
\hline $\mathbf{A}_{5}$ & 123.41 & 137.03 & 130.22 \\
\hline $\mathbf{A}_{6}$ & 70.38 & 77.96 & 74.17 \\
\hline SE (m) & 0.92 & 1.89 & 1.01 \\
\hline CD (5\%) & 2.62 & 5.38 & 2.89 \\
\hline \multicolumn{4}{|l|}{ (B) Varieties } \\
\hline $\mathrm{B}_{1}$ & 91.68 & 100.30 & 95.99 \\
\hline $\mathbf{B}_{2}$ & 93.91 & 102.77 & 98.34 \\
\hline $\mathbf{B}_{3}$ & 96.13 & 105.83 & 100.98 \\
\hline $\mathbf{B}_{4}$ & 97.77 & 108.46 & 103.12 \\
\hline $\mathrm{SE}(\mathrm{m})$ & 0.75 & 1.54 & 0.83 \\
\hline CD (5\%) & 2.14 & 4.39 & 2.36 \\
\hline
\end{tabular}




\section{Yield per hectare}

It is evident from the data presented in (Table 3). Maximum yield per hectare calculated under $\mathrm{A}_{5}\left(\mathrm{GA}_{3} 50 \mathrm{ppm}+\right.$ Cycocel $2000 \mathrm{ppm}+$ KNO3@0.2\%+ZnSO $@$ @0.3\%+Boron@ $0.1 \%)$ i.e. $123.41 \mathrm{q}, 137.03 \mathrm{q}$ and $130.22 \mathrm{q}$ followed by $\mathrm{A}_{4}\left(\mathrm{GA}_{3} 50 \mathrm{ppm}+\right.$ Cycocel 1000 ppm+ KNO3@0.2\%+ZnSO $@$ @ 0.3\% + Boron@0.1\%) i.e. $106.09 \mathrm{q}, 115.59 \mathrm{q}$ and 110.84 q, A3 (GA3 50 ppm + KNO3 @ 0.2\% +ZnSO4@ 0.3\% + Boron @ 0.1\%) i.e. 96.54 q, $105.60 \mathrm{q}$ and $101.07 \mathrm{q}$ while the minimum yield per hectare recorded under $\mathrm{A}_{6}$ (Control) i.e. $70.38 \mathrm{q}, 77.96 \mathrm{q}$ and $74.17 \mathrm{q}$ during first year, second year and pooled data.

Among the varieties, $\mathrm{B}_{4}$ (Sai Sarbati) recorded maximum yield per hectare i.e. $97.77 \mathrm{q}, 108.46 \mathrm{q}$ and $103.12 \mathrm{q}$. It was followed by $\mathrm{B}_{3}$ (Pramalini) i.e. $123.41 \mathrm{q}$, $137.03 \mathrm{q}$ and $130.22 \mathrm{q}$ and $\mathrm{B}_{2}$ (Vikram) i.e. $123.41 \mathrm{q}, 137.03 \mathrm{q}$ and $130.22 \mathrm{q}$ while the minimum yield per hectare recorded with $\mathrm{B}_{1}$ (Kagzi lime) i.e. $123.41 \mathrm{q}, 137.03 \mathrm{q}$ and 130.22 q during first year, second year and pooled data. All the varieties were found insignificant to each other.

Yield parameters and yield viz., number of fruits per tree, yield per tree and yield per hectare were significantly increased by different varieties. $\mathrm{B}_{4}$ (Sai Sarbati) recorded highest number of fruits per tree, yield per tree as well as yield per hectare followed by $\mathrm{B}_{3}$ (Pramalini) and $\mathrm{B}_{1}$ (Kagzi lime) while the minimum values were observed with $B_{2}$ (Vikram).

Present investigation revealed that various yield parameters like number of fruits per tree, yield per tree and yield per hectare were significantly increased by application of different PGR and micronutrients. Higher number of fruits per trees was recorded in $\mathrm{A}_{5}$ $\left(\mathrm{GA} 350 \mathrm{ppm}+\right.$ Cycocel $2000 \mathrm{ppm}+\mathrm{KNO}_{3}$
@0.2\%+ZnSO $\mathrm{Zn}_{4} @ 0.3 \%+$ Boron@0.1\%) followed by $\mathrm{A}_{4}\left(\mathrm{GA}_{3} 50 \mathrm{ppm}+\right.$ Cycocel 1000 ppm+KNO3@0.2\%+ZnSO $\mathrm{Zn}_{4} @ 0.3 \%+$ Boron@0.1\%) and $\mathrm{A}_{3}\left(\mathrm{GA}_{3} 50 \mathrm{ppm}+\right.$ KNO3@0.2\%+ZnSO $90.3 \%+$ Boron@ $0.1 \%$ ) while the maximum values was found under $\mathrm{A}_{6}$ (Control). The results are in conformity with findings of Tripathi and Dhakal (2005) and Devi et al., (2011) in acid lime. Go Guey (1990) reported increase in the number of fruits per tree with the application of $\mathrm{GA}_{3}$, Cycocel, $\mathrm{KNO}_{3}, \mathrm{ZnSO}_{4}$ and Boron significantly increases number of fruits per panicle and tree particularly in pruned mango trees. Maximum number of fruits could be due to increase the hormonal activity by pruning and increase number of perfect flowers, flower set, fruit set and retention by cycocel application. Jagtap et al., (2013) who reported significant increase in the number of fruits per tree with the application of $\mathrm{GA}_{3} 200$ ppm in Kagzi lime. The increase the number of fruits per tree with the application of $\mathrm{GA}_{3}$, Cycocel, $\mathrm{KNO}_{3}, \mathrm{ZnSO}_{4}$ and Boron could be attributed to increase flower set observed with the treatments initially resulting in the more number of fruits per tree.

Highest yield per tree as well as per hectare was recorded in $\mathrm{A}_{5}\left(\mathrm{GA}_{3} 50 \mathrm{ppm}+\right.$ Cycocel 2000 ppm+KNO3@0.2\%+ZnSO4@0.3\% + Boron@0.1\%) followed by $\mathrm{A}_{4}$ (GA3 50 ppm + Cycocel 1000 ppm+ KNO3 @ 0.2\% +ZnSO4@0.3\%+Boron @ 0.1\%) and $\mathrm{A}_{3}$ (GA350 ppm+KNO3@0.2\%+ZnSO4@ $0.3 \%$ + Boron @ 0.1\%) while the maximum values was found under $\mathrm{A}_{6}$ (Control). The increased fruit yield attributed to the synthesis of chlorophyll from source to sink which leads to increase carbohydrate metabolism. This might be due to more vegetative growth attained with $\mathrm{GA}_{3}$, which increased the vegetative shoot development at the initial sprays. Cycocel sprays enhancing flower bud initiation. $\mathrm{KNO}_{3}$ sprays could have helped to set more fruits leading highest yield per tree. 
The results are in accordance with the findings of Mukunda et al., (2014) with spraying $\mathrm{GA}_{3} 50$ ppm during June + CCC @ 1000 ppm during September $+\mathrm{KNO}_{3} 2 \%$ during October on acid lime cv. Balaji reported the highest tree yield.

Yield is the culmination of the inter play of several factors like biochemical, physiological and yield parameters. The increase in yield might be due to more fruit set, fruit retention and number of fruits per tree. An increase in fruit yield per tree might be due to more availability of gibberellic acid. Gibberellic acid promotes cell elongation, cell enlargement, increases in number of cells and also helps in increasing fruit volume, diameter and weight ultimately the fruit yield per tree.

The results are in agreement with the findings of Thirugnanavel et al., (2007) in acid lime, Jain et al., (2014) high yield noticed with $\mathrm{GA}_{3}$ 100 ppm in Nagpur mandarin. Narayanlal et al., (2013) who reported the highest yield per plant was found in $50 \mathrm{ppm} \mathrm{GA}_{3}$ in guava. Debbarma and Hazarika (2016) also reported the $\mathrm{GA}_{3} @ 100$ ppm + CCC @ 1000 ppm + $\mathrm{KNO}_{3} 1 \%$ increases the yield in acid lime. Combined effect of varieties and PGR and micronutrients had exerted non-significant influence on yield and yield parameters.

The present result on acid lime concludes that different PGR and varieties significantly increased various yield parameters in comparison to control. Besides it, $\mathrm{A}_{5}$ (GA3 50 ppm + Cycocel 2000 ppm+ KNO3@0.2\% +ZnSO4@0.3\%+Boron@0.1\%), A4 (GA3 50 ppm + Cycocel 1000 ppm+ KNO3@0.2\% +ZnSO4@0.3\%+Boron@0.1\%) and A3 (GA3 50 ppm + KNO3@0.2\%+ZnSO4@ $0.3 \%+$ Boron @ 0.1\%) helped more to achieve the desired value for different yield parameters. So it is recommended to use these in combinations to obtain more yield and better quality of acid lime and to achieve maximum benefit under the existing agroclimatic conditions of Gwalior region of Madhya Pradesh. On the other hand there were little differences observed within the varieties which were tested. B4 (Sai Sarbati), B3 (Pramalini), B2 (Vikram) and B1 (Kagzi lime) respond well with different PGR and micronutrients.

\section{References}

Babu, R. (2001). Lime and lemons. Handbook of horticulture, ICAR. New Delhi. 212 pp.

Debbarma, N. and Hazarika, B.N. (2016). Effect of plant growth regulators and chemicals on yield and quality of acid lime (Citrus aurantifolia Swingle) under foot hill condition of Arunachal Pradesh. International Journal of Agriculture, Environment and Biotechnology. 9(2): 231-236.

Devi, H. L.; Sarkar, S.K.; Dhanabati, L. and Majhi, D. (2011). Flushing - flowering behavior and regulation in acid lime - A critical review and research interventions. $J$. of Crop and Weed. 7(2): 87-90.

Go Guey, T. (1990). The effect of repeated application of cultar (paclobutrazol) to Mangifera indica L.var. Valencia. Fruit-Paris. 45(6): 599-607.

Jagtap, V.M, Patel, H.C, Nehet, D.S. and Godage, S.S. (2013). Effect of foliar application of plant growth regulators and micronutrients on yield and quality of acid lime cv. Kagzi (Citrus aurantifolia Swingle). The Asian Journal of horticulture. 8(1): 57-59.

Jain, M.C, Choudhary, H.D, Sharma, M.K. and Bhim Singh. (2014). Yield and quality attributes of Nagpur mandarin as affected by use of different plant growth regulators. Environment and Ecology, 32: 1141-45. 
Mukunda, L.L, Venkata Ramana, K.T, Sivarama Krishna, V.N.P, Yuvaraj, K.M, Nagalakshmi, T, Sarada, G, Gourisankar, T, Gopi, V. and Gopal, K. (2014). Effect of growth regulators and chemicals on fruit yield and quality of hasta bahar flowering in acid lime (citrus aurantifolia swingle) cv. Balaji. Journal of Agriculture and Allied Sciences. 3(3): 11-13.

Narayanlal, Das, R.P. and Verma, L.R. (2013). Effect of plant growth regulators on flowering Salunakhe, D. K. and Desai, B. B. (1984). Postharvest Biotechnology of Fruits. Vol. 2. Boca Raton, Florida. CRC. Press, Inc., USA, $148 \mathrm{pp}$.
Thirugnanavel, A., Amutha, R., Baby Rani, W., Indira, K., Mareeswari, S., Muthulaksmi, S. and Parthiban, S. (2007). Studies on regulation of flowering in acid lime (Citrus aurantifolia Swingle). Research J. of Agri. and Biological Sciences. 3(4): 239-241.

Tripathi, K.M. and Dhakal, D.D. (2005). Effect of paclobutrazol on off-season flower induction in acid lime (Citrus aurantifolia Swingle) land races under Chitwan condition. Journal of the Institute of Agriculture and Animal Science. 26: 87-92.

\section{How to cite this article:}

Vasure, N., A.K. Barholia, R. Bajpai, R. Jatav and Pippal, R. 2018. Effect of Foliar Application of Growth Regulators and Micronutrients on Fruit Yield Attributes of Acid Lime (Citrus aurantifolia Swingle). Int.J.Curr.Microbiol.App.Sci. 7(09): 213-219. doi: https://doi.org/10.20546/ijcmas.2018.709.027 